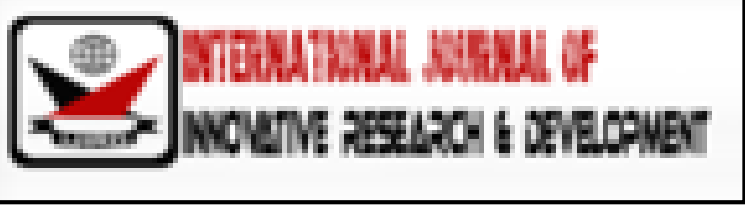

ISSN 2278 - 0211 (Online)

\title{
Role of Insect Pollinators in the Pollination of Coconut: Cocos Nucifera at Asante Mampong Municipality in Ashanti Region of Ghana
}

\author{
Dr. E. B. Borketey-La \\ Senior Lecturer, Department of Crops and Soil Science, \\ University of Education, Winneba, Ghana
}

\begin{abstract}
This research was conducted in the Asante Mampong Municipality in the Ashanti Region of Ghana from 27th June, 2018 to 16th October, 2019. The core objective of the study was to investigate into the role of insect pollinators in the pollination of three varieties of coconut (Cocosnucifera) on Coconut Plantation at Asante Mampong Municipality.

A five acre Coconut plantation was established in the year 2008. The major coconut varieties grown are namely; Hybrid Tall (HT), Malayan Yellow Dwarf (MYD) and Equatorial Guinea Dwarf (EGD). These varieties were grown in rows but mixed together with the inter row distance $7.5 \mathrm{~m} X 7.5 \mathrm{~m}$ for the short varieties and $9.0 \mathrm{~m} X 9.0 \mathrm{~m}$ for the tall varieties.

Six (6) individual coconut plants were selected randomly from each variety, making a total of eighteen (18) coconut plants for the investigation based upon their fruiting requirements using simple random sampling.

The results from the study showed that, there were more cross-pollination than self-pollination in Hybrid Tall (HT) and Malayan Yellow Dwarf (MYD). Both cross-pollination than self-pollination took place in Equatorial Guinea Dwarf (EGD).

Seven (7) insect species were found as coconut flower visitors. Out of the seven, three (3)species namely honey bees (Apismellifera) and stingless bees (Dactylurina spp. and Meliponula spp)

Were the potential pollinators. Housefly (Orinidiaspp), Wasps are occasional flower visitors foraging for resources for their colony. Ants were numerous but their structure and movement may have no effect on pollination.

Observation of foraging insects and pollinator counts were done on the inflorescence of the selected coconut plants. The foraging activities of bees occur at mid-day (11:0am-2:00pm) after which their activities gradually decline drastically (3:00pm-6:00pm). Intense foraging of bees occurs when temperature was between $27^{\circ} \mathrm{C}$ to $29^{\circ} \mathrm{C}(12: 00 \mathrm{pm}-2: 00 \mathrm{pm})$. Dactylurinasppprefers higher temperature than Apismellifera and Meliponula spp. Abundant Dactylurinaspp were observed at the temperature range of $27^{\circ} \mathrm{C}$ to $29^{\circ} \mathrm{C}$ between12:00pm - 2:00pm whiles Apismellifera and Meliponulaspp were also in abundant at the temperature $27^{\circ} \mathrm{C}$ between 12:00pm-1:00pm.
\end{abstract}

Keywords: Coconut, pollination, pollinators, temperature, insect species, hybrid tall, Malayan yellow dwarf and Equatorial Guinea dwarf

\section{Introduction}

The coconut palm (Cocosnucifera) is the most known member of the palm family (Habibullahet al., 2014 and Fan et al., 2013). It is the only species recognized in the genus Cocosandbelongs to the family Arecaceae (Palm family), (Fan et al., 2013 and Freitas et al., 2016). In many cultures around the world the local name for the coconut palm translates to "tree of life", or "tree of heaven", because of the numerous uses and products derived from the coconut palm (Rasheed et al., 2016 and Verkley et al., 2014 and Freitas et al., 2016). C. nuciferais found throughout the tropics, with different varieties in different locations (Rasheed et al., 2016 and Verkley et al., 2014, Fan et al., 2013 and Freitas et al., 2016). In the southern parts of Ghana, coconut palms of the 'West African Tall' variety are common (Loiola et al., 2016 and Lima et al 2015).

The origins of the coconut palm, based on genetic analysis and origination of 'Dwarf' cultivars, are in Southeast Asia and the islands around the seas surrounding Indonesia and Malaysia (Habibullahet al., 2014, Verkley et al., 2014 and Fan et al., 2013). From its origin, it naturally spread west to the east coast of Africa and east among the tropical islands of the Pacific (Habibullahet al., 2014). Coconut would not have reached the west coast of Africa without human aid because of its inability to survive the duration of travel and southern climactic conditions that fall outside the coconut temperature tolerance. In addition, the coconut would not be able to compete in a trans-continental spread. Humans aided the spread of the coconut from West Africa to the Caribbean (Rasheed et al., 2016, Loiola et al., 2016 and Verkley et al., 2014).

The introduction of the coconut palm to Ghana occurred about 500 years ago, within 50 years of 1499, when the Portuguese brought the coconut to the Atlantic coast of Africa (Habibullahet al., 2014 and Lima et al2015). The coconut 
palm was important along the coastal region due to the contribution to trade routes, but was not immediately of commercial importance. After World War I, however, large communal coconut plantations were established along the coast, in Ghana, with stimulation for the markets coming from both African and European interests (Iliffe, 2015 and Freund 2016). By the end of 1936, there were at least 5,693.4 hectares (14,076 acres) of coconut plantations located in southern Volta as well as the Eastern, Central, and Western regions.

There two main classifications of varieties which are the 'Tall' and the 'Dwarf'. 'Tall' varieties are more common. The fruit of the coconut is spherical to oblong in shape, and occur in bunches on the palm. They grow slowly and bear fruits 6 to 10 years after planting. As male flowers mature earlier than the female flowers, this type is highly crosspollinated. 'Dwarf' varieties are generally shorter in stature and have thinner stem, fruit earlier, and have smaller fruits than the 'tall' varieties. Due to overlapping of male and female phases, the dwarf varieties are self-pollinated. (Rasheed et al., 2016 and Loiola et al., 2016).

Coconut provides man with food, drink, fuel oil and many other products. The coconut water is nutrient rich, almost perfectly isotonic, and aseptic enough to be used as an IV fluid and the kernel of the coconut, known for its high-oil content, is rich in saturated fatty acids (Rasheed et al., 2016, and Loiola et al., 2016). Saturated fatty acids are normally considered non-nutritious; however, evidence points to the contrary for fatty acids derived from the coconut (De Souzaet al., 2015). In fact, coconut oil is traditionally used medicinally for many illnesses. Some Pacific Islanders view coconut oil as the cure for all illness (Eyreset al., 2016). The amount and quality of oil in the kernel, however, varies among the variety and age of the coconut (De Souzaet al., 2015).

\subsection{The Objective of This Study Was Therefore:}

The main purpose of the study is to investigate into the Role of Insect Pollinators in the Pollination of Three Varieties of Coconut (Cocos nucifera) at Asante Mampong Municipality in Ashanti Region of Ghana.

\section{Materials and Methods}

\subsection{The Study Area}

\subsubsection{Description of the Study Area}

\subsubsection{Geographical Location}

The field experiments were carried out at the Coconut plantation site of the College of Agriculture Education, University of Education, Winneba, Mampong-Ashanti from $17^{\text {th }}$ July, 2018 to $16^{\text {th }}$ October, 2019. Mampong Municipality is located north -east of Kumasi, the Ashanti regional capital. It is bounded to the north by Atebubu District in the Brong Ahafo Region, east by Sekyere Central, south by Sekyere South and Ejura-Sekyedumasi to the West. The Municipality which covers a total land area of approximately $782 \mathrm{~km}^{2}$ with 69 settlements has geographical locationlying between latitudes $7^{\circ} 4^{\prime} 0^{\prime \prime}$ North of the Equator and longitudes $1^{\circ} 24^{\prime} 0$ " West of the Greenwish Merindian. If respect to the plantation site, it covers an area of $14681.1 \mathrm{~m}^{2}$, distance 450 meters.

\subsection{Setting of the Study}

The study was carried out to investigate the role of insect pollinators in the pollination of three varieties of coconut (Cocosnucifera) on CAGRIC coconut plantation. The Coconut plantation was established in the year 2008 with the total acreage of five (5) acres. The major coconut varieties grown are namely; Hybrid Tall (HT), Malayan Yellow Dwarf (MYD) and Equatorial Guinea Dwarf (EGD).

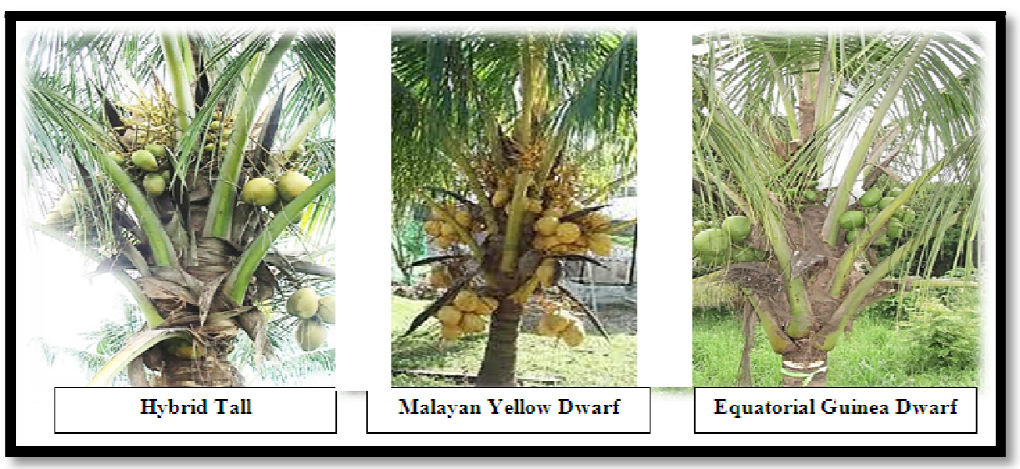

Figure 1.1: The Three Varieties of Coconut on CAGRIC Plantation

These varieties have grown in rows but mixed together with the inter row distance $7.5 \mathrm{~m} X 7.5 \mathrm{~m}$ for the short varieties and $9.0 \mathrm{~m} \mathrm{X} 9.0 \mathrm{~m}$ for the tall varieties.

\subsection{Sample Population and Sampling Procedure}

Out of the three (3) major varieties of coconut in the plantation, six (6) individual coconut plants were selected randomly from each variety, making a total of eighteen (18) coconut plants for the investigation. That is, Hybrid Tall (HT): 
HT1, HT2, HT3, HT4, HT5, HT6, Malayan Yellow Dwarf (MYD): MYD1, MYD2, MYD3, MYD4, MYD5, MYD6 and Equatorial Guinea Dwarf (EGD): EGD1, EGD2, EGD3, EGD4, EGD5, EGD6.

The three (3) main coconut varieties were identified in farm, and in each case, six (6) plants were selected based upon their fruiting requirements using simple random sampling.

\subsection{Data Collection}

\subsubsection{Testing For Self-Pollination And Cross-Pollination In Coconut}

The pollination experiment was conducted between $27^{\text {th }}$ June, 2018 to $16^{\text {th }}$ October, 2019, approximately 12 weeks. Six plants each from the three varieties of coconut in the plantation were sampled and bagged. The bagging was done on $27^{\text {th }}$ June, $1^{\text {st }}$ July and 19th July 2018. Bagging was done at least 6 days before any of the female flowers in an emasculated inflorescence became receptive. The receptivity of a female flower is denoted by the splitting of the white stigma and the secretion of nectar. The rectangular muslin net (bag) was slipped over the unopened inflorescence with its opening coming down over the peduncle and tied with a copper wire to prevent any flower-visiting insects from entering. The muslin net was of a fine mesh size so as to prevent any foreign pollen and insect from passing through. Daily observation was done on the set-up. Counting and recording of the female flowers was done after the opening of the spadix. As soon as the stigma of all female flowers necroses or turns brownish-black, the bag was removed and the female fruits counted and recorded.

The average number of fruit per plant for six plants per variety were added and divided by six for the mean number of fruits per variety (Malhotra et al, 2017, Abrol, 2015 and JAMATIA, 2016).

\subsubsection{Sampling and Collection of Pollinators}

The survey for pollinators was conducted between $27^{\text {th }}$ June, 2018 to $16^{\text {th }}$ October, 2019. Sampling was done by the researcher. The method that was used to sample pollinators was similar to Perera et al., 2016, Larekeng et al., 2015 andPashte and Kulkarni, 2015). A quadrat measuring 1 meter by 1 meter was demarcated (Walters and hansen, 2013) and six (6) plants $30 \mathrm{~m}$ apart were sampled and tagged.

Hourly observation begun from 06:00am - 05:00pm for foraging and pollinators counts was done on flowers. Observation of foraging and pollinators counts were done on inflorescence flowering. Observations were made under conditions favourable for insects' fliglit, sunny or cool weather and weak wind. Sweep net sampling was used to reach pollination in the canopy of coconut. Sampling was done to collect flower visiting insects of the coconut bloom (JASMI, 2017and Delaplaneet al., 2013).

During the hourly observation, insect activities were observed and recorded under the following: insects that visited female flowers, insects that visited male flowers, insects that visited male flowers and moved to female flowers and insects that visited female flowers and moved to the male flowers. An opened spadix was scanned for pollination. Each inflorescence was observed for five minutes. A visit was defined as occurring when an insect touched the anthers or stigmas. Hourly temperature was taken to match with pollinator abundance recorded. This was done by the help of mercury-in-glass thermometer.

The sampled insects were killed by drowning in soapy water, cleaned in clear water by shaking and preserved in $70 \%$ alcohol. Samples of preserved insects were sent to taxonomists at the insect museum of the Entomology and Wildlife Development for identification. Dried and pinned specimens of insect pollinators were kept in the insect museum of the Development of Entomology and Wildlife, University of Cape Coast. The number of pollinators encountered per tree was taken as abundance.

\subsection{Data Analysis}

\subsubsection{Comparison of Cross Pollination to Self-Pollination}

The mean number of fruits for cross-pollination and self-pollination of each variety was calculated, significance was tested using ANOVA.

\subsubsection{Bagging Experiment}

Fruits that were formed in each bagged (self-pollination) and unbagged (open-pollination) were recorded. Total number of bagged and unbagged from each tree were added and divided by two for average fruit per tree, the average number of fruits per tree for five trees in the landscape were added and divided by five for the mean number of fruits in the landscapes.

\subsubsection{Species Composition of Insect Flower Visitors for Three Coconut Varieties}

Species composition on total insect abundance was calculated and tabulated. Data on hourly insect visitor abundance per tree for the three varieties were recorded with hourly temperature reading. This information was used to plot graph to display effect of temperature on foraging. 


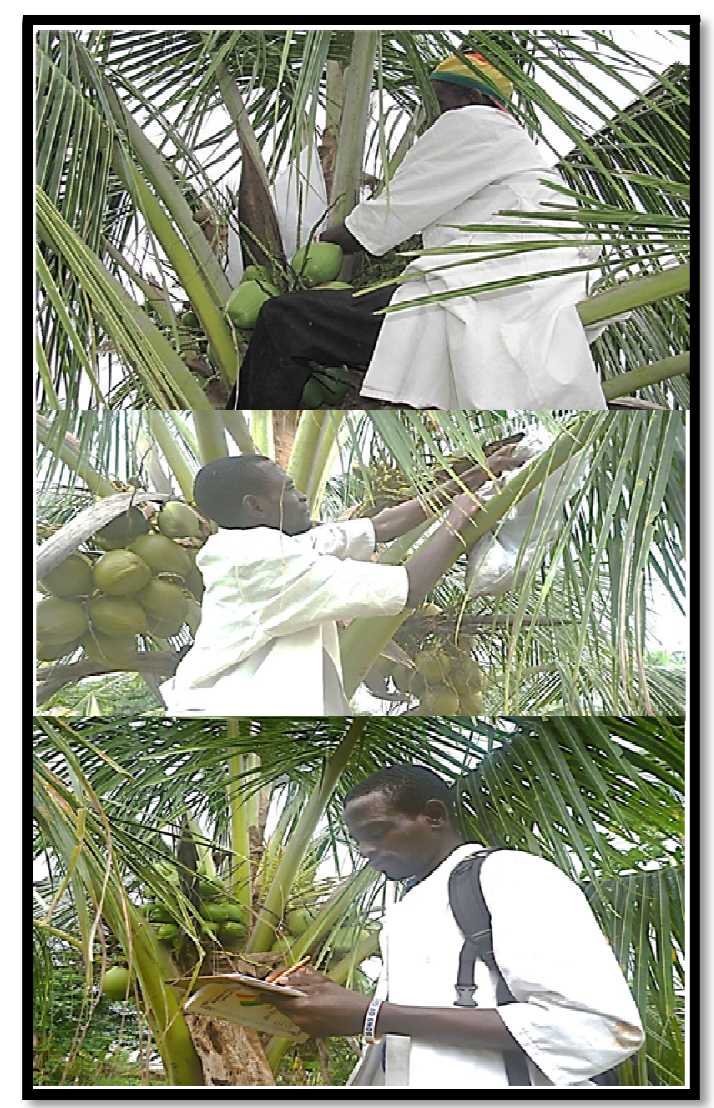

Figure 2: Investigation into the Type of Pollination

\subsection{Investigation into the Type of Pollination System}

The results indicated different means for the varieties. Fruit formation due to cross-pollination for Hybrid Tall (HT) was higher (10.00) than that for self-pollination (2.67). T-test analysis indicated that cross-pollination is significantly higher $(\mathrm{p}<0.008)$ than self-pollination.

Results on Malayan Yellow Dwarf (MYD) indicate that cross-pollination (13.00) is higher than self-pollination (4.00). T-test analysis indicated that cross-pollination is significantly higher $(\mathrm{p}=0.032)$ than self-pollination therefore the null hypothesis $\left(\mathrm{H}_{0}=\mathrm{CP}=\mathrm{SP}\right)$ is rejected in both cases and the alternate hypothesis $(\mathrm{HA}=\mathrm{CP} \neq \mathrm{SP})$ accepted for $\mathrm{HT}$ and MYD. There is more cross-pollination than self-pollination in HT and MYD.

For Equatorial Green Dwarf (EGD) field results indicated that, cross-pollination (11.83) was higher than self-pollination (5.00). However, $t$-test analysis indicated that the difference is not significant therefore the null hypothesis $\left(\mathrm{H}_{0}=\mathrm{CP}=\mathrm{SP}\right)$ is accepted that there is no difference between cross-pollination and self-pollination. The HA $=\mathrm{CP} \neq \mathrm{SP}$ is rejected. Therefore both cross-pollination and self-pollination are taking place.

\begin{tabular}{|c|c|c|c|c|c|c|c|c|}
\hline & \multicolumn{2}{|c|}{ Type of Pollination } & & & & \\
\hline $\begin{array}{c}\text { Coconut } \\
\text { variety }\end{array}$ & $\begin{array}{c}\text { Opened } \\
\text { Inflorescence }\end{array}$ & $\begin{array}{c}\text { Bagged } \\
\text { Inflorescence }\end{array}$ & Mean & Std. Deviation & $\begin{array}{c}\text { Std. Error } \\
\text { Mean }\end{array}$ & T & Df & $\begin{array}{c}\text { Sig. } \\
\text { (2-Tailed) }\end{array}$ \\
\hline $\begin{array}{c}\text { Hybrid } \\
\text { Tall }\end{array}$ & 10.00 & 2.67 & 7.33 & 4.18 & 1.71 & 4.29 & 5 & 0.008 \\
\hline $\begin{array}{c}\text { Equatorial } \\
\text { Green } \\
\text { Dwarf }\end{array}$ & 11.83 & 5.00 & 6.83 & 11.37 & 4.64 & 1.47 & 5 & 0.201 \\
\hline $\begin{array}{c}\text { Malayan } \\
\text { Yellow } \\
\text { Dwarf }\end{array}$ & 13.00 & 4.00 & 9.00 & 7.48 & 3.06 & 2.95 & 5 & 0.032 \\
\hline
\end{tabular}

Table 1: Investigation into the Type of Pollination

Means followed by the same letter in superscript are not significantly different based on least significant (LSD) test at $95 \%$ significance level.

\subsection{Species Composition of Insect Flower Visitors for Three Coconut Varieties}

Seven species of insects were collected foraging on the three varieties of coconut and they consist of Ants, Honey Bee (Apismellifera), Housefly (Orinidiaspp), Stingless Bee (Dactylurinaspp and Meliponulaspp), Big Wasp and Medium Wasp. 


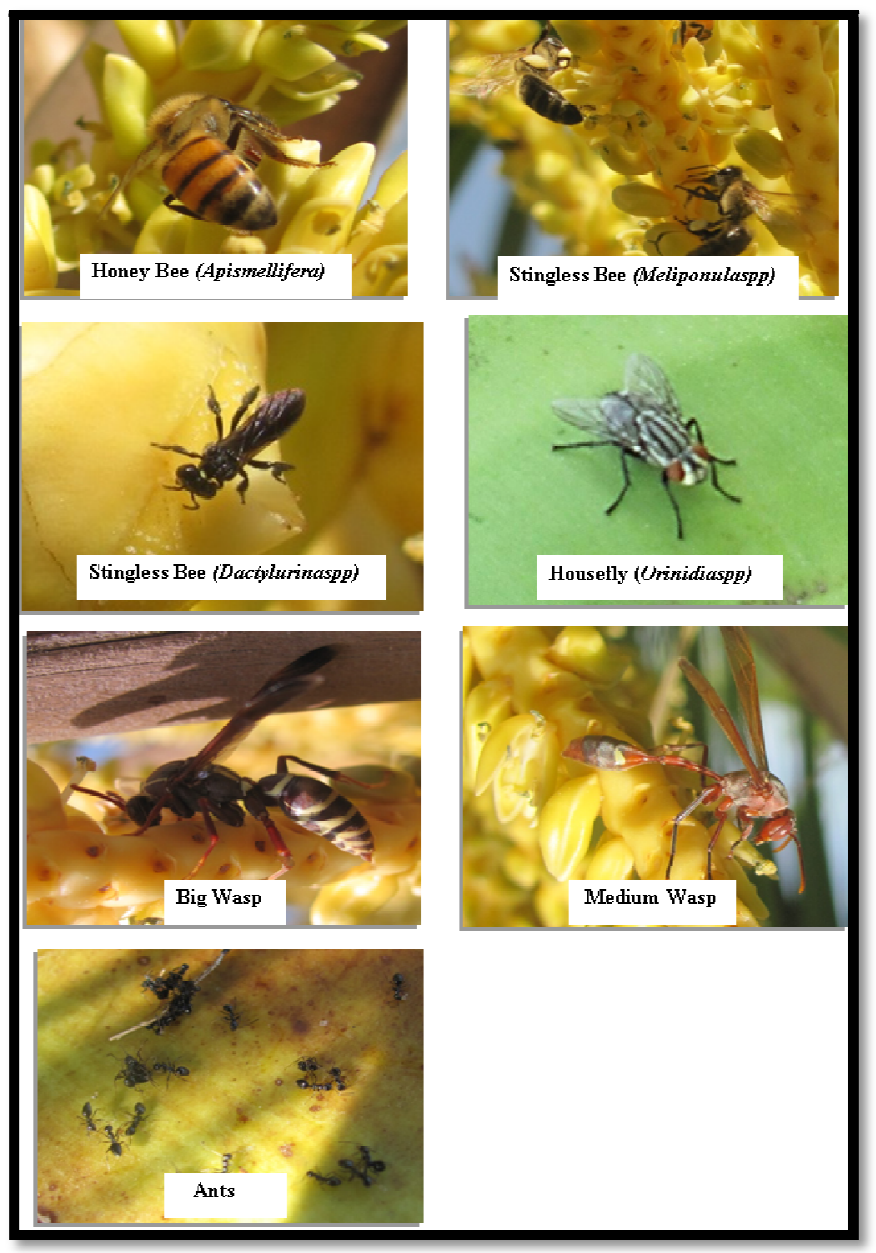

Figure 3: Species Composition of Insect Flower Visitors for Three Coconut Varieties

Honey bee (Apismellifera), and Stingless Bees (Dactylurinaspp and Meliponulaspp), seem to be the major pollinators of coconut because they have special adaptive feature for the collection of pollen grain (the pollen basket on the hind leg). They were seen foraging on flower and storing pollen in their pollen basket and insects moved from male to female flowers, this may result in pollination. There were a lot of ants on all the varieties but their movement does not follow any order and seem not to contribute to coconut pollination. Wasps (Big and Medium) and Housefly are occasional visitors. Number of insect species on types: 6 on EGD and HT, 5 on MYD. Honey bees and ants were dominant on EGD (19.54) whiles Honey bees were dominant in HT (21.33) and MYD (20.63).

\begin{tabular}{|c|c|c|c|c|c|c|}
\hline & \multicolumn{6}{|c|}{ Variety of Coconut } \\
\hline & \multicolumn{2}{|c|}{$\begin{array}{c}\text { Equatorial Green } \\
\text { Dwarf (EGD) }\end{array}$} & \multicolumn{2}{c|}{ Hybrid Tall (HT) } & \multicolumn{2}{c|}{$\begin{array}{c}\text { Malayan Yellow Dwarf } \\
\text { (MYD) }\end{array}$} \\
\hline Insect Type & Frequency & $\mathbf{( \% )}$ & Frequency & $\mathbf{( \% )}$ & Frequency & (\%) \\
\hline Ants & 203 & 19.54 & 129 & 13.83 & 146 & 15.45 \\
\hline $\begin{array}{c}\text { Honey Bee } \\
\text { Apismellifera) }\end{array}$ & 203 & 19.54 & 199 & 21.33 & 195 & 20.63 \\
\hline $\begin{array}{c}\text { Housefly } \\
\text { (Orinidiaspp) }\end{array}$ & 8 & 0.77 & 4 & 0.43 & 0 & 0.00 \\
\hline $\begin{array}{c}\text { Stingless Bee } \\
\text { (Dactylurinaspp) }\end{array}$ & 169 & 16.27 & 99 & 10.61 & 179 & 18.94 \\
\hline $\begin{array}{c}\text { Stingless Bee } \\
\text { (Meliponulaspp) }\end{array}$ & 29 & 2.79 & 37 & 3.97 & 33 & 3.49 \\
\hline Wasp (Big) & 11 & 1.06 & 14 & 1.50 & 2 & 0.21 \\
\hline Wasp (Medium) & 8 & 0.77 & 6 & 0.64 & 8 & 0.85 \\
\hline
\end{tabular}

Table 2: Species Composition of Insect Flower Visitors for Coconut Variety

The Effects of Environmental Temperature on the Abundance of Foraging Insect Pollinators (Apismellifera, Dactylurinaspp, Meliponulaspp).

Foraging activities of coconut flower visitors seem to be influenced by environmental temperature and time visit. 
Inspection started at 6:00am when temperature was low $\left(23^{\circ} \mathrm{C}\right)$ and foraging was relatively low. Mean number of Apis melliferaforaging by $6: 00 \mathrm{am}$ at $23^{\circ} \mathrm{C}$ was 4.0 . This increased gradually and peaked to a mean number of 11.0 by $12.00 \mathrm{noon}$ when the temperature was $27^{\circ} \mathrm{C}$. Foraging deceased gradually after falling to a mean of 9.0 by $5.00 \mathrm{pm}$ at $25^{\circ} \mathrm{C}$.

Dactylurinaspp foraging by 6:00am at $23^{\circ} \mathrm{C}$ was 8.0 . By $10.00 \mathrm{am} 25^{\circ} \mathrm{C}$, no Dactylurinaspp was encountered. However, mean number of Dactylurinaspp peaked to a mean of 13.0 by $12: 00$ noon at $27^{\circ} \mathrm{C}$. Number of the insect fluctuated till $5: 00 \mathrm{pm}$ at $25^{\circ} \mathrm{C}$ when 4.0 speices was encountered.

Mean number of Meliponulasppen countered by 6:00am at $23^{\circ} \mathrm{C}$ was 1.0 . This fluctuated and peaked (8.0) by $1.00 \mathrm{pm}$ at $28^{\circ} \mathrm{C}$. It gradually declined to $4.0 \mathrm{by} 5.00 \mathrm{pm}$ at $25^{\circ} \mathrm{C}$.

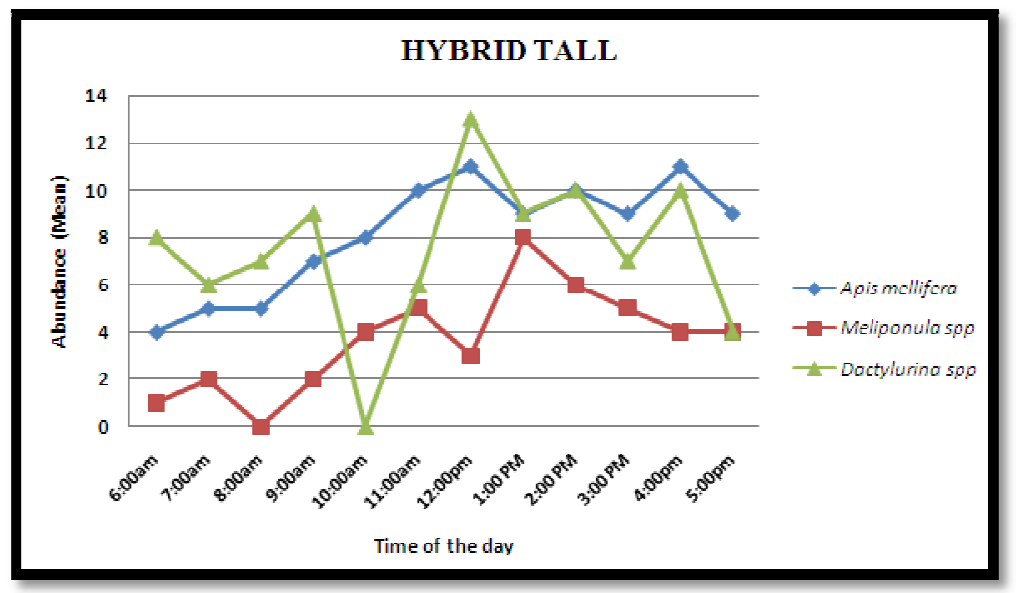

Figure 4: The Effects of Temperature on the Abundance of Insect Pollinators on Hybrid Tall

\subsection{The Effects of Temperature on the Abundance of Foraging Insect Pollinators on Equatorial Green Dwarf (EGD)}

The environmental temperature and time of the day influenced the foraging activities of coconut flower visitors especially the potential pollinators.

Inspection started at 6:00am when temperature was low $\left(23^{\circ} \mathrm{C}\right)$ and foraging was relatively low. Mean number of Apis mellifera foraging by $6: 00 \mathrm{am}$ at $23^{\circ} \mathrm{C}$ was 2.0 . This fluctuated and peaked with a mean number of 20.0 by $12.00 \mathrm{noon}$ when the temperature was $27^{\circ} \mathrm{C}$. Foraging deceased gradually after falling to a mean of 15.0 by $5.00 \mathrm{pm}$ at $25^{\circ} \mathrm{C}$.

No Dactylurinaspp foraging was recorded by 6:00am at $23^{\circ} \mathrm{C}$ till $8: 00 \mathrm{am}$ at $24^{\circ} \mathrm{C}$. By $9.00 \mathrm{am}$ at $24^{\circ} \mathrm{C}$, the number of insects started increasing gradually from 1.0 and peaked with a mean number of 27.0 by 2.00 pm when the temperature was $29^{\circ} \mathrm{C}$. Foraging deceasedgradually after falling to a mean of 5.0 by $5.00 \mathrm{pm}$ at $25^{\circ} \mathrm{C}$.

There was no foraging of Meliponulaspp by $6: 00 \mathrm{am}$ at $23^{\circ} \mathrm{C}$. This fluctuated and peaked (8.0) by $12.00 \mathrm{pm}$ at $27^{\circ} \mathrm{C}$ and gradually declined to 7.0 by $4.00 \mathrm{pm}$ at $27^{\circ} \mathrm{C}$ and the same mean was recorded 5:00pm at $25^{\circ} \mathrm{C}$.

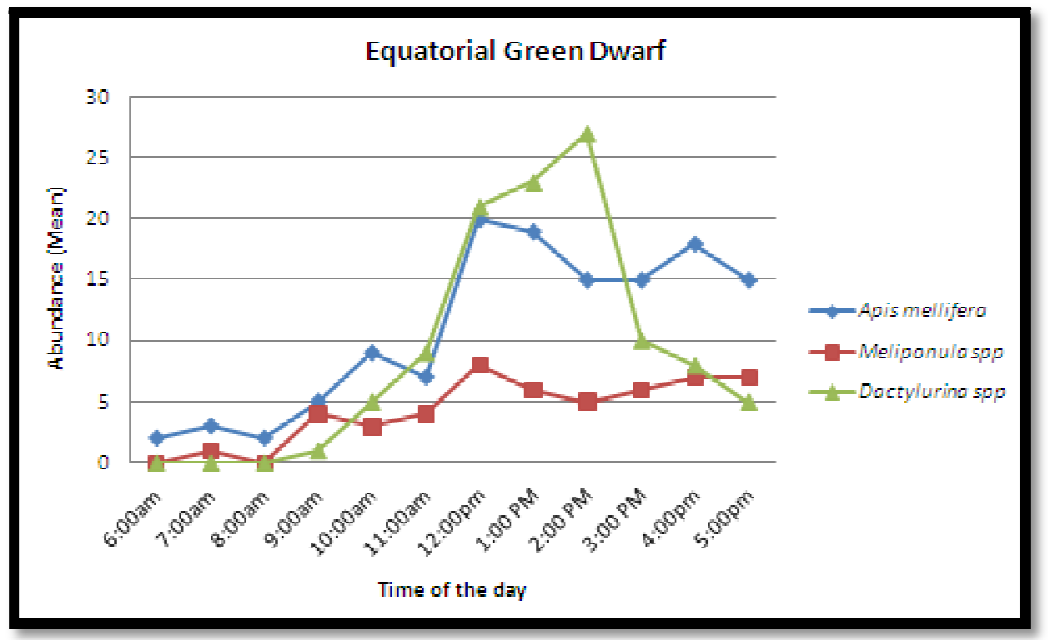

Figure 5: The Effects of Temperature on the Abundance of Insect Pollinators on Equatorial Green Dwarf (EGD)

\subsection{The Effects of Temperature on the Abundance of Foraging Insect Pollinators on Malayan Yellow Dwarf (MYD)}

The environmental temperature and time of the day influenced the foraging activities of coconut flower visitors especially the potential pollinators.

At 6:00am when temperature was low $\left(23^{\circ} \mathrm{C}\right)$, the inspection started and foraging was relatively low. The mean number of Apis mellifera foraging by 6:00am and 7:00am at $23^{\circ} \mathrm{C}$ was 5.0 .This fluctuated and peaked with a mean number of 20.0 by 2.00 noon at $29^{\circ} \mathrm{C}$ being the highest temperature. Foraging deceased gradually to a mean of 15.0 at $3: 00 \mathrm{pm}$ and $4: 00 \mathrm{pm}$ with temperature $28^{\circ} \mathrm{C}$ and $27^{\circ} \mathrm{C}$. However,by $5.00 \mathrm{pm}$ at $25^{\circ} \mathrm{C}$ the mean was 17.0 . 
No Dactylurinaspp foraging recorded by 6:00am and 7:00am at $23^{\circ} \mathrm{C}$. However, by $8.00 \mathrm{am}$ at $24^{\circ} \mathrm{C}$, the number of insects started increasing gradually from 2.0 and peaked to a mean number of 25.0 by 2.00 pm when the temperature was $29^{\circ} \mathrm{C}$. Foraging deceased gradually after falling to a mean of 7.0 by $5.00 \mathrm{pm}$ at $25^{\circ} \mathrm{C}$.

There was 1.0 Meliponulaspp foraging by $6: 00 \mathrm{am}$ at $23^{\circ} \mathrm{C}$. This fluctuated and peaked (10.0) by $12.00 \mathrm{pm}$ and $4: 00 \mathrm{pm}$ at $27^{\circ} \mathrm{C}$ respectively and declined to 9.0 by $5.00 \mathrm{pm}$ at $25^{\circ} \mathrm{C}$.

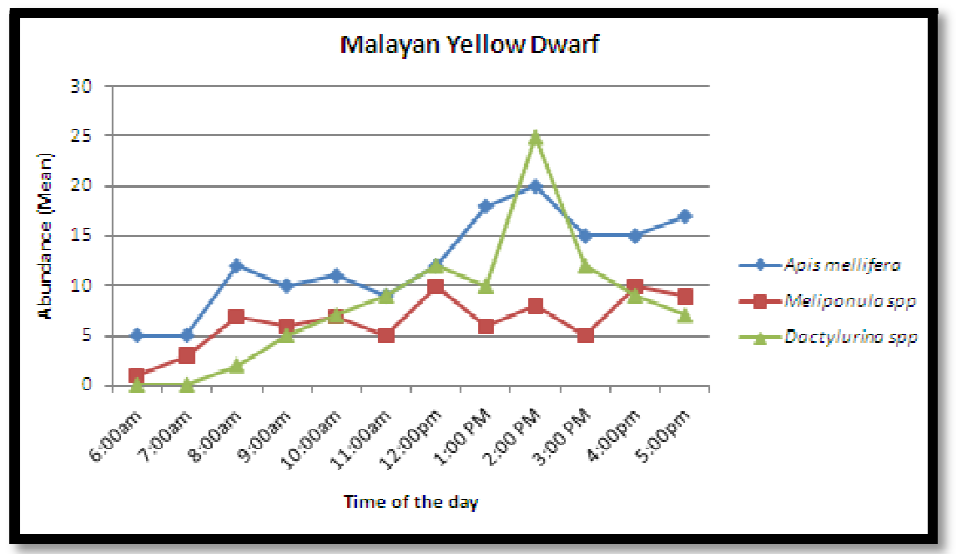

Figure 6: The Effects of Temperature on the Abundance of Insect Pollinators on Malayan Yellow Dwarf

\section{Discussion}

\subsection{Investigation into the Type of Pollination System}

The results indicated that more cross-pollination than self-pollination took place in Hybrid Tall (HT) and Malayan Yellow Dwarf (MYD). This result confirms that of Thomaset al., 2015, Gunn et al., 2015and Dinesh and Vasug (2016) who reported that, Tall variety has greater genetic variability as it is usually cross pollinated.

The field observation also indicated that, for Equatorial Guinea Dwarf (EGD), both cross-pollination and selfpollination occurred. These results are in consistent with Chan and Rasheed et al., 2016, and Loiola et al., 2016 who reported that, the male and female flowers of dwarf varieties of coconut mature at different times, encouraging cross pollination; however, self-pollination is possible.

\subsection{Species Composition of Insect Flower Visitors for Three Coconut Varieties}

Among other insects, bees appear to attain highest abundance and species richness in the tropics, as well as the temperate regions (Edwardset al, 2014 and Pardee et al, 2014). In the tropics, honey bees and stingless bees are dominant. Honey bees have been recorded as potential pollinators (Goulsonet al., 2015 and Fürs et al., 2014). Certain groups of flies such as fruit flies are omnipresent on palm inflorescence in the tropics, but probably have less consequence for pollination (Buchmann, 2016, Martin 2014 and Thiessen, 2016).

The results of the study in Table 4.2 indicate that, Seven (7) insect species were found as coconut flower visitors. This is in line with Henderson, (2002) and Sholdt, (1966) who reported that a number of insects visit the coconut inflorescence. Out of the seven, three (3) species; honey bees (Apismellifera) and stingless bees (Dactylurina spp. and Meliponula spp.) may be potential pollinators. The present result is consistent with those that indicate that honey bees (Apismellifera) are the dominant flower visitors. This is consistent with (Edwardset al, 2014 and Pardeeet al, 2014). Honey bees are probably the most important pollinators (Goulsonet al., 2015 and Fürs et al., 2014).) Followed by stingless bees. This is because they presented the most appropriate foraging strategy of moving from the staminate flowers to thepistillate flower and cause accidental pollination (Abrol 2015 and Lok et al., 2013). They are also equipped with adaptive structures with which they carry pollen grain andalso carry pollen on their ventral surfaces which cause pollination as they move from the anthers to the stigma (Loket al., 2013) Housefly (Orinidiaspp), wasp are occasional flower visitors foraging for resources for their colony. In addition, wasps have been reported to deter bees from foraging temporarily when present (Mattila and Seeley2014, Groulx, 2016).Ants were numerous during the study period but their structure and movement may have no effect on pollination.

\subsection{The Effects of Environmental Temperature on the Abundance of Insect Pollinators}

The time of day when honeybees start and finish foraging often depends on ambient temperature, humidity and/or light levels, as well as the availability of floral resources the specific combination of factors is species-specific (Abrol 2015 and Lok et al., 2013). Studies have shown that foraging and pollination are influenced by temperature ((Lok et al., 2013 and Goulsonet al., 2015).

From the results in figure 4.3, it can be deduced that most of the foraging activities of bees often occur mid-day $(11: 00 \mathrm{pm}-2: 00 \mathrm{pm})$ but from $(3: 00 \mathrm{pm}-6: 00 \mathrm{pm})$ their activities gradually decline drastically. Intense foraging of honey bees occur when temperature is between $27^{\circ} \mathrm{C}$ to $29^{\circ} \mathrm{C}$. Dactylurinaspp prefers higher temperature than Apismellifera and Meliponula spp. Abundant Dactylurinaspp were observed at the temperature range from $27^{\circ} \mathrm{C}$ to $29^{\circ} \mathrm{C}(12: 00 \mathrm{pm}-2: 00 \mathrm{pm})$ whiles Apismellifera and Meliponulaspp were also in abundant at the temperature $27^{\circ} \mathrm{C}(12: 00 \mathrm{pm}-1: 00 \mathrm{pm})$. These 
observations were encountered among the three varieties of coconut. This is consistent with Houdegbe et al., 2016 and Hamisi 2016), that Dactylurinaspp prefers higher temperature for their foraging activities than Apismellifera and Meliponulas spp.

\section{Conclusion}

From the study, it was concluded that more cross-pollination than self-pollination took place in Hybrid Tall (HT) and Malayan Yellow Dwarf (MYD). This result confirms that of Thomaset al., 2015, Gunn et al., 2015 and Dinesh and Vasug (2016) who reported that, Tall variety has greater genetic variability as it is usually cross pollinated. The field observation also indicated that, for Equatorial Guinea Dwarf (EGD), both cross-pollination and self-pollination occurred. These results are in consistent with Chan and Rasheed et al., 2016, and Loiola et al., 2016 who reported that, the male and female flowers of dwarf varieties of coconut mature at different times, encouraging cross pollination; however, self-pollination is possible.

Seven species of insects were collected foraging on the three varieties of coconut and they consist of Ants, Honey Bee (Apis mellifera), Housefly (Orinidia spp), Stingless Bee (Dactylurina spp and Meliponula spp), Big Wasp and Medium Wasp. Honey bee (Apis mellifera), and Stingless Bees (Dactylurina spp and Meliponula spp), seem to be the major pollinators of coconut because they have special adaptive feature for the collection of pollen grain (the pollen basket on the hind leg). They were seen foraging on flower and storing pollen in their pollen basket and insects moved from male to female flowers, this may result in pollination. There were a lot of ants on all the varieties but their movement does not follow any order and seem not to contribute to coconut pollination.

The environmental temperature and time of the day influences the foraging activities of coconut flower visitors especially the potential pollinators. For Hybrid Tall variety, Mean number of Apis melliferaforaging by 6:00am at $23^{\circ} \mathrm{C}$ was 4.0. This increased gradually and peaked to a mean number of 11.0 by 12.00 noon when the temperature was $27^{\circ} \mathrm{C}$. Foraging deceased gradually after falling to a mean of 9.0 by $5.00 \mathrm{pm}$ at $25^{\circ} \mathrm{C}$. Dactylurina spp foraging by 6:00am at $23^{\circ} \mathrm{C}$ was 8.0. By $10.00 \mathrm{am} 25^{\circ} \mathrm{C}$, no Dactylurina spp was encountered. However, mean number of Dactylurina spp peaked to a mean of 13.0 by $12: 00$ noon at $27^{\circ} \mathrm{C}$. Number of the insect fluctuated till $5: 00 \mathrm{pm}$ at $25^{\circ} \mathrm{C}$ when 4.0 speices was encountered. Mean number of Meliponula spp encountered by 6:00am at $23^{\circ} \mathrm{C}$ was 1.0 . This fluctuated and peaked (8.0) by $1.00 \mathrm{pm}$ at $28^{\circ} \mathrm{C}$. It gradually declined to 4.0 by $5.00 \mathrm{pm}$ at $25^{\circ} \mathrm{C}$.

For Equatorial Green Dwarf, Inspection started at 6:00am when temperature was low $\left(23^{\circ} \mathrm{C}\right)$ and foraging was relatively low. Mean number of Apis mellifera foraging by $6: 00 \mathrm{am}$ at $23^{\circ} \mathrm{C}$ was 2.0 . This fluctuated and peaked with a mean number of 20.0 by 12.00 noon when the temperature was $27^{\circ} \mathrm{C}$. Foraging deceased gradually after falling to a mean of 15.0 by $5.00 \mathrm{pm}$ at $25^{\circ} \mathrm{C}$. No Dactylurina spp foraging was recorded by $6: 00 \mathrm{am}$ at $23^{\circ} \mathrm{C}$ till $8: 00 \mathrm{am}$ at $24^{\circ} \mathrm{C}$. By $9.00 \mathrm{am}$ at $24^{\circ} \mathrm{C}$, the number of insects started increasing gradually from 1.0 and peaked with a mean number of 27.0 by $2.00 \mathrm{pm}$ when the temperature was $29^{\circ} \mathrm{C}$. Foraging deceased gradually after falling to a mean of 5.0 by $5.00 \mathrm{pm}$ at $25^{\circ} \mathrm{C}$. There was no foraging of Meliponula spp by 6:00am at $23^{\circ} \mathrm{C}$. This fluctuated and peaked (8.0) by $12.00 \mathrm{pm}$ at $27^{\circ} \mathrm{C}$ and gradually declined to 7.0 by $4.00 \mathrm{pm}$ at $27^{\circ} \mathrm{C}$ and the same mean was recorded $5: 00 \mathrm{pm}$ at $25^{\circ} \mathrm{C}$.

For the Malayan Yellow Dwarf, At 6:00am when temperature was low $\left(23^{\circ} \mathrm{C}\right)$, the inspection started and foraging was relatively low. The mean number of Apis mellifera foraging by 6:00am and 7:00am at $23^{\circ} \mathrm{C}$ was 5.0.This fluctuated and peaked with a mean number of 20.0 by $2.00 \mathrm{pm}$ at $29^{\circ} \mathrm{C}$ being the highest temperature. Foraging deceased gradually to a mean of 15.0 at $3: 00 \mathrm{pm}$ and $4: 00 \mathrm{pm}$ with temperature $28^{\circ} \mathrm{C}$ and $27^{\circ} \mathrm{C}$. However,by $5.00 \mathrm{pm}$ at $25^{\circ} \mathrm{C}$ the mean was 17.0 . No Dactylurina spp foraging recorded by 6:00am and 7:00am at $23^{\circ} \mathrm{C}$. However, by $8.00 \mathrm{am}$ at $24^{\circ} \mathrm{C}$, the number of insects started increasing gradually from 2.0 and peaked to a mean number of 25.0 by $2.00 \mathrm{pm}$ when the temperature was $29^{\circ} \mathrm{C}$. Foraging deceased gradually after falling to a mean of $7.0 \mathrm{by} 5.00 \mathrm{pm}$ at $25^{\circ} \mathrm{C}$.There was 1.0 Meliponula spp foraging by 6:00am at $23^{\circ} \mathrm{C}$. This fluctuated and peaked $(10.0)$ by $12.00 \mathrm{pm}$ and $4: 00 \mathrm{pm}$ at $27^{\circ} \mathrm{C}$ respectively and declined to 9.0 by $5.00 \mathrm{pm}$ at $25^{\circ} \mathrm{C}$.

\section{References}

i. Abrol, D. P. (2015). Berry Fruits. In Pollination Biology, Vol. 1(pp. 209-270). Springer, Cham.

ii. Abrol, D. P. (2015). Tropical Fruits. In Pollination Biology, Vol. 1 (pp. 271-345). Springer, Cham.

iii. Buchmann, S. (2016). The Reason for Flowers: Their History, Culture, Biology, and how They Change Our Lives. Simon and Schuster.

iv. De Souza, R. J., Mente, A., Maroleanu, A., Cozma, A. I., Ha, V., Kishibe, T.,.. \& Anand, S. S. (2015). Intake of saturated and unsaturated fatty acids and risk of all-cause mortality, cardiovascular disease, and type 2 diabetes: systematic review and meta-analysis of observational studies. Bmj, 351, h3978.

v. Delaplane, K. S., Dag, A., Danka, R. G., Freitas, B. M., Garibaldi, L. A., Goodwin, R. M., \& Hormaza, J. I. (2013). Standard methods for pollination research with Apis mellifera. Journal of Apicultural Research, 52(4), 1-28.

vi. Dinesh, M. R., \& Vasugi, C. (2016). Guava improvement in India and future needs. Journal of Horticultural Science, 5(2), 94-108.

vii. Edwards, D. P., Tobias, J. A., Sheil, D., Meijaard, E., \& Laurance, W. F. (2014). Maintaining ecosystem function and services in logged tropical forests. Trends in ecology \& evolution, 29(9), 511-520.

viii. Eyres, L., Eyres, M. F., Chisholm, A., \& Brown, R. C. (2016). Coconut oil consumption and cardiovascular risk factors in humans. Nutrition reviews, 74(4), 267-280.

ix. Fan, H., Xiao, Y., Yang, Y., Xia, W., Mason, A. S., Xia, Z. ...\& Tang, H. (2013). RNA-Seq analysis of Cocos nucifera: transcriptome sequencing and de novo assembly for subsequent functional genomics approaches. PloS one, 8(3), e59997. 
X. Freitas, C., Meerow, A. W., Pintaud, J. C., Henderson, A., Noblick, L., Costa, F. R., ... \& Barrington, D. (2016). Phylogenetic analysis of Attalea (Arecaceae): insights into the historical biogeography of a recently diversified Neotropical plant group. Botanical journal of the Linnean Society, 182(2), 287-302.

xi. Freund, B. (2016). The making of contemporary Africa: the development of African society since 1800. Palgrave Macmillan.

xii. Fürst, M. A., McMahon, D. P., Osborne, J. L., Paxton, R. J., \& Brown, M. J. F. (2014). Disease associations between honeybees and bumblebees as a threat to wild pollinators. Nature, 506(7488), 364.

xiii. Goulson, D., Nicholls, E., Botías, C., \& Rotheray, E. L. (2015). Bee declines driven by combined stress from parasites, pesticides, and lack of flowers. Science, 347(6229), 1255957.

xiv. Groulx, A. (2016). Nesting aggregation as a Determinant of Brood Parasitism in Mason Bees (Osmia spp.) (Doctoral dissertation, Université d'Ottawa/University of Ottawa).

xv. Gunn, B. F., Baudouin, L., Beulé, T., Ilbert, P., Duperray, C., Crisp, M. ...\& Rival, A. (2015). Ploidy and domestication are associated with genome size variation in Palms. American journal of botany, 102(10), 1625-1633.

xvi. Habibullah, M., Masjuki, H. H., Kalam, M. A., Fattah, I. R., Ashraful, A. M., \& Mobarak, H. M. (2014). Biodiesel production and performance evaluation of coconut, palm and their combined blend with diesel in a single-cylinder diesel engine. Energy Conversion and Management, 87, 250-257.

xvii. Hamisi, I. (2016). Diversity, status and threats to stingless bees (Apidae: Meliponini) of Ipembampazi Forest Reserve, Tabora-Tanzania (Doctoral dissertation, Sokoine University of Agriculture).

xviii. Houdegbe, C. A., Sogbohossou, O. E., \& Achigan-Dako, E. G. (2016). Utilization and breeding perspective in the egusi gourd Melothria sphaerocarpa (Cogn.) H. Schaef. et SS Renner (syn: Cucumeropsis mannii Naudin). Genetic resources and crop evolution, 63(3), 545-559.

xix. Iliffe, J. (2015). Emergence of African Capitalism. Springer.

xx. Jamatia, J. (2016). Morphological And Molecular Characterization Of Citrullus Species And Studies Of Inter Specific Hybridisation (Doctoral Dissertation, Division Of Vegetable Science Indian Agricultural Research Institute New Delhi).

xxi. JASMI, J. (2017). Diversity and blooming season of food sources plant of Apis cerana (Hymenoptera: Apidae) in polyculture plantation in West Sumatra, Indonesia. Biodiversitas Journal of Biological Diversity, 18(1).

xxii. Larekeng, S. H., Maskromo, I., Purwito, A., Matjik, N., \& Sudarsono, S. (2015). Pollen dispersal and pollination patterns studies in Pati kopyor coconut using molecular markers. Intl J CORD, 31(1), 46-60.

xxiii. Lima, E. B. C., Sousa, C. N. S., Meneses, L. N., Ximenes, N. C., Juniors, S., Vasconcelos, G. S., ... \& Vasconcelos, S. M. M. (2015). Cocos nucifera (L.)(Arecaceae): A phytochemical and pharmacological review. Brazilian Journal of Medical and Biological Research, 48(11), 953-964.

xxiv. Loiola, C. M., Azevedo, A. O. N., Diniz, L. E., Aragão, W. M., Azevedo, C. D. D. O., Santos, P. H. A., ... \& Ramos, S. R. R. (2016). Genetic relationships among tall coconut palm (Cocos nucifera L.) accessions of the International Coconut Genebank for Latin America and the Caribbean (ICG-LAC), evaluated using microsatellite markers (SSRs). PloS one, 11(3), e0151309.

xxv. Lok, A. F. S. L., Ang, W. F., Ng, B. Y. Q., Leong, T. M., Yeo, C. K., \& Tan, H. T. (2013). Native fig species as a keystone resource for the Singapore urban environment. Raffles Museum of Biodiversity Research. National University of Singapore, Singapore Google Scholar.

xxvi. Malhotra, S. K., Hubballi, V. N., \& Nayak, M. G. (2017). CASHEW: Production, Processing and Utilization of Byproducts. Processing and Utilization of By-products Directorate of Cashewnut and Cocoa Development, Cochin, Kerala, India.

xxvii. Martin, D. (2014). Edible: An adventure into the world of eating insects and the last great hope to save the planet. Houghton Mifflin Harcourt.

xxviii. Mattila, H. R., \& Seeley, T. D. (2014). Extreme polyandry improves a honey bee colony's ability to track dynamic foraging opportunities via greater activity of inspecting bees. Apidologie, 45(3), 347-363.

xxix. Pardee, G. L., \& Philpott, S. M. (2014). Native plants are the bee's knees: local and landscape predictors of bee richness and abundance in backyard gardens. Urban ecosystems, 17(3), 641-659.

xxx. Pashte, V. V., \& Kulkarni, S. R. (2015). Role of Pollinators in Qualitative Fruit Crop Production: A Review. Trends in Biosciences, 8(15), 3743-3749.

xxxi. Perera, L., Baudouin, L., \& Mackay, I. (2016). SSR markers indicate a common origin of self-pollinating dwarf coconut in South-East Asia under domestication. Scientia Horticulturae, 211, 255-262.

xxxii. Rasheed, A. A., Perveen, A. N. J. U. M., Abid, R. O. O. H. I., \& Qaiser, M. U. H. A. M. M. A. D. (2016). Pollen morphology of the subfamily Arecoideae Griff. (family-Arecaceae) from Pakistan and Kashmir. Pak. J. Bot, 48(3), 1051-1060.

xxxiii. Thiessen, T. (2016). Borneo. Bradt Travel Guides.

xxxiv. Thomas, R. J., Rajesh, M. K., Jacob, P. M., Jose, M., \& Nair, R. V. (2015). Studies on genetic uniformity of Chowghat Green Dwarf and Malayan Green Dwarf varieties of coconut using molecular and morphometric methods. Journal of Plantation Crops, 43(2), 89-96.

xxxv. Verkley, G. J. M., Dukik, K., Renfurm, R., Göker, M., \& Stielow, J. B. (2014). Novel genera and species of coniothyrium-like fungi in Montagnulaceae (Ascomycota). Persoonia: Molecular Phylogeny and Evolution of Fungi, 32, 25.

xxxvi. Walters, B. B., \& Hansen, L. (2013). Farmed landscapes, trees and forest conservation in Saint Lucia (West Indies). Environmental conservation, 40(3), 211-221. 